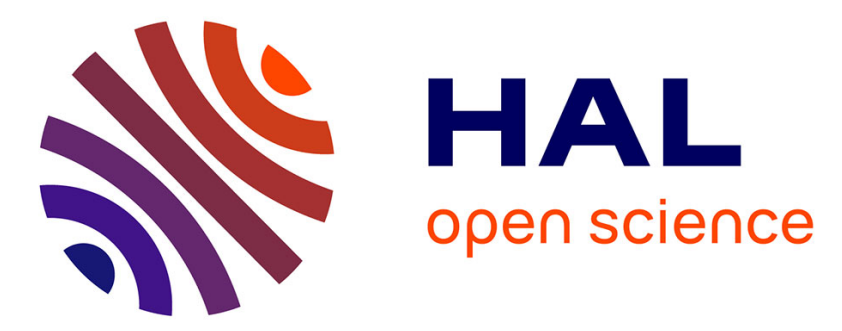

\title{
Contrasting shell growth strategies in two Mediterranean bivalves revealed by oxygen-isotope ratio geochemistry: The case of Pecten jacobaeus and Glycymeris pilosa
}

Melita Peharda, Julien Thébault, Kresimir Markulin, Bernd R. Schone, Ivica Janekovic, Laurent Chauvaud

\section{To cite this version:}

Melita Peharda, Julien Thébault, Kresimir Markulin, Bernd R. Schone, Ivica Janekovic, et al.. Contrasting shell growth strategies in two Mediterranean bivalves revealed by oxygen-isotope ratio geochemistry: The case of Pecten jacobaeus and Glycymeris pilosa. Chemical Geology, 2019, 526, pp.2335. 10.1016/j.chemgeo.2017.09.029 . hal-02402956

\section{HAL Id: hal-02402956 https://hal.science/hal-02402956}

Submitted on 18 Jun 2020

HAL is a multi-disciplinary open access archive for the deposit and dissemination of scientific research documents, whether they are published or not. The documents may come from teaching and research institutions in France or abroad, or from public or private research centers.
L'archive ouverte pluridisciplinaire HAL, est destinée au dépôt et à la diffusion de documents scientifiques de niveau recherche, publiés ou non, émanant des établissements d'enseignement et de recherche français ou étrangers, des laboratoires publics ou privés. 


\title{
Contrasting shell growth strategies in two Mediterranean bivalves revealed by oxygen-isotope ratio geochemistry: The case of Pecten jacobaeus and Glycymeris pilosa
}

\author{
Melita Peharda $^{\mathrm{a}, *}$, Julien Thébault ${ }^{\mathrm{b}}$, Krešimir Markulin ${ }^{\mathrm{a}}$, Bernd R. Schöne ${ }^{\mathrm{c}}$, Ivica Janeković ${ }^{\mathrm{d}, e}$, \\ Laurent Chauvaud ${ }^{\mathrm{b}}$ \\ a Institute of Oceanography and Fisheries, Split, Croatia \\ b Université de Bretagne Occidentale, Institut Universitaire Européen de la Mer, Laboratoire des Sciences de l'Environnement Marin (UMR6539 UBO/IRD/CNRS), \\ Plouzané, France \\ c Johannes Gutenberg-Universität Mainz, Institut für Geowissenschaften, Mainz, Germany \\ d Rudjer Bošković Institute, Division for Marine and Environmental Research, Zagreb, Croatia \\ e The University of Western Australia, Perth, Australia
}

\section{A R T I C L E I N F O}

\section{Keywords:}

Sclerochronology

Mediterranean

Adriatic

Stable-isotope ratio geochemistry

Bivalve shells

\begin{abstract}
A B S T R A C T
High-resolution stable-isotope ratio data $\left(\delta^{18} \mathrm{O}, \delta^{13} \mathrm{C}\right)$ were used to study growth strategies of two bivalve species, Pecten jacobaeus (calcitic shell) and Glycymeris pilosa (aragonitic shell) from the North Adriatic Sea. The principal objectives of this study were to identify the period of the year when the growth line is formed in the shell of two target species, to identify the main growing season of these two species, to identify the environmental drivers of shell growth, and to evaluate the potential applicability of $\delta^{18} \mathrm{O}$ and $\delta^{13} \mathrm{C}$ values for the reconstruction of environmental variability. Samples were collected from the North Adriatic Sea by commercial bean trawl (P. jacobaeus, December 2013 and January 2014, N = 4) and SCUBA diver (Glycymeris pilosa, March 2016, $N=3$ ). Samples for the oxygen $\left(\delta^{18} \mathrm{O}\right)$ and carbon $\left(\delta^{13} \mathrm{C}\right)$ isotope composition of the calcium carbonate were collected by drilling the outer shell layer across several annual cycles. Temporal and spatial temperature and salinity values inside the investigated area were simulated using the 3D numerical ocean model - ROMS. The $\delta^{18} \mathrm{O}$ cycles corresponded to the number of seasonal growth marks observed on the external shell surface of both target species, thereby confirming the annual periodicity of these growth patterns. In February 2012, extreme cooling of the water column accompanied by dense water formation occurred in the Adriatic Sea - an event recorded by $P$. jacobaeus shells. This study indicates that $P$. jacobaeus and $G$. pilosa have contrasting shell growth strategies. Pecten jacobaeus grows during winter and slows shell growth during the warmest part of the year, and thereby may be an interesting archive for winter conditions. Due to its longevity and continuous growth during the warmest part of the year, G. pilosa is a promising archive for the reconstruction of summer seawater temperatures.
\end{abstract}

\section{Introduction}

Over the past decade, the field of sclerochronology has been rapidly developing by investigating structural elements, as well as the geochemical composition of bivalve shells, with the objective of obtaining information on environmental conditions archived during the lifetime of an organism (Schöne and Gillikin, 2013). Analysis of oxygen-isotope ratios $\left(\delta^{18} \mathrm{O}\right)$ of mollusk shell carbonates has become a key tool for paleoclimate reconstruction as this data can be used to estimate the temperature of the ambient water at the time of shell formation, when $\delta^{18} \mathrm{O}_{\text {water }}$ is known (Urey, 1947; Epstein et al., 1953; Grossman and Ku,
1986; Schöne and Surge, 2005; Gröcke and Gillikin, 2008; Oschmann, 2009; Wanamaker et al., 2011; Schöne and Gillikin, 2013; Butler and Schöne, 2017; Prendergast et al., 2017). Although the interpretation of $\delta^{13} \mathrm{C}$ data is often less straightforward because of species-specific metabolic effects (Chauvaud et al., 2011; Marchais et al., 2015), stable carbon-isotope ratio signatures of mollusk shells may provide data on salinity and $\delta^{13} \mathrm{C}_{\mathrm{DIC}}$ values in estuarine environments (Gillikin et al., 2006; McConnaughey and Gillikin, 2008). These records can range from daily to sub-seasonal time-scales, depending on growth rate and longevity of the studied species, and can provide data for recent years and decades, as well as past centuries (e.g. Black et al., 2009; Butler

\footnotetext{
* Corresponding author.

E-mail address: melita@izor.hr (M. Peharda).
} 
et al., 2013; Schöne, 2013; Reynolds et al., 2016).

Despite having the analytical capabilities for isotope ratios and the tools for milling/drilling shells readily available, only a few studies have investigated the isotopic geochemistry of Mediterranean bivalve shells. Richardson et al. (2004), Bušelić et al. (2015) and Peharda et al. (2015) applied stable-isotope ratio analyses for the validation of periodicity of growth line formation in Adriatic Sea bivalves Pinna nobilis, Glycymeris bimaculata, and Lithophaga lithophaga, respectively. Purroy Albet (2017) used oxygen isotopes for the identification of the main growing season of Callista chione and Glycymeris bimaculata in the Adriatic. In a recent study, Crippa et al. (2016) performed stable isotope analysis of fossil shells of several bivalve species from the lower Pleistocene Arda river marine succession (northern Italy). To the best of our knowledge, the only studies on the potential of stable-isotope ratios in recent bivalve shells in the Mediterranean for paleoclimate reconstruction are that of Maier and Titschack (2010) on Spondylus gaederopus and García-March et al. (2011) on Pinna nobilis.

According to a number of studies, the Mediterranean Sea might be an especially vulnerable region to global climate change (e.g. Giorgi and Lionello, 2008; Adloff et al., 2015; Mariotti et al., 2015). These studies agree that Mediterranean region is expected to become substantially drier and warmer during the twenty-first century, especially in the warm season. In the context of possible ecological and environmental changes, understanding drivers of growth in marine organisms is crucial to forecast the impact of climate change on marine biota, and marine bivalve shells present an excellent archive for this purpose. This study comparatively analyzes two bivalve species with different life strategies (as detailed below), the commercially important Mediterranean scallop Pecten jacobaeus (Peharda et al., 2003) and the long living bittersweet clam Glycymeris pilosa ( $>50$ years, Peharda et al., 2016).

Due to their fast growth rates and high commercial value associated with fishing, as well as aquaculture activities, scallops have been subject of numerous studies. Shell oxygen-isotope ratios were successfully applied to determine the ontogenetic age of several Pectinidae species (e.g. Krantz et al., 1984; Dare and Deith, 1990; Lasta et al., 2001; Heilmayer et al., 2003; Chute et al., 2012). Besides ageing, the application of oxygen-isotope ratios for (paleo-) environmental reconstructions has been evaluated (e.g. Hickson et al., 1999; Chauvaud et al., 2005; Thébault et al., 2007; Trevisol et al., 2012; Jolivet et al., 2015).

Pecten jacobaeus is the largest scallop inhabiting the Mediterranean Sea and can attain a shell length of up to 140-160 mm (Marguš et al., 1992; Onofri and Marguš, 1995; Peharda et al., 2003). This species lives at depths ranging from 25 to $250 \mathrm{~m}$, on sand, mud and gravel substrates (Poppe and Goto, 2000). Although it is present throughout the Mediterranean coastal waters, it occurs in exploitable quantities only in the Northern Adriatic (Mattei and Pelizzato, 1996). Significant variation in the biomass of $P$. jacobaeus fished in the North Adriatic occurred over the last four decades. During 1970 to 2000, the annual landing at the Chioggia fish market (Italy), the main port for scallop fishing in the Adriatic, varied between 105 and 1172 tons (mean \pm standard deviation $=551 \pm 326$ tons), with a subsequent significant decrease, with average annual landings of only $56 \pm 19$ tons (Mazzoldi et al., 2014; Clodia database, 2015). Although overfishing is probably the main reason behind the decrease in landings, it is possible that environmental factors, such as seawater temperature, salinity, oxygen saturation and food availability, might have also negatively affected growth as well as other biological processes in P. jacobaeus.

The second target species, G. pilosa, a longlived bivalve (maximum of about 70 years) that was recently proposed as a potential environmental archive to investigate the relationship between climate and biology in the Mediterranean (Peharda et al., 2016). Species of Glycymeris were previously identified as targets for sclerochronological research and chronologies spanning several decades have been constructed using G. glycymeris from the North-East Atlantic (Brocas et al., 2013; Reynolds et al., 2013; Royer et al., 2013). According to Reynolds et al. (2013), maximum longevity of G. glycymeris is $\sim 200$ years, whereas Peharda et al. (2016) estimated the maximum longevity of $G$. pilosa at $\sim 70$ years. Although it was previously thought that G. glycymeris inhabits the Mediterranean and Adriatic Seas, a recent study by Purroy et al. (2016) identified this species as G. pilosa raising the need for a better understanding of the ecology and shell growth of this species. Because of distinct annual growth lines (Peharda et al., 2016), G. pilosa has a great potential for paleoclimate reconstructions, but there is the need for understanding the timing of growth line formation, as well as the rate of seasonal growth, in order to properly interpret chronologies in terms of environmental variations in the Mediterranean Sea.

The principal objectives of this study were to: i) identify the period of the year when the growth line is formed in the shell of two target species, P. jacobaeus (calcitic shell) and G. pilosa (aragonitic shell); ii) identify the main grow season of these two species; iii) identify the environmental drivers of shell growth; and iv) evaluate the potential applicability of $\delta^{18} \mathrm{O}$ values for the reconstruction of environmental variability.

\section{Materials and methods}

\subsection{Environmental variables}

Daily mean temperature and salinity fields inside the investigated area (offshore of West Istria) were modeled using the 3D numerical model ROMS with a spatial resolution of $2 \mathrm{~km}$ and 20 "s" level coordinates in the vertical (Janeković et al., 2014). In this study we used results only at the bottom for temperature and salinity parameters, computed previously within the Adriatic Sea ROMS modelling study. The model was integrated for 6 years starting from 2008 till the end of 2014 and was validated in many studies with available observations (e.g. CTD profiles and satellite SST in Janeković et al., 2010, 2014; Vilibić et al., 2016). During the period 2009-2014, the model used realistic atmospheric forcing, lateral boundary conditions, and freshwater input from 41 rivers providing accurate estimates for all model state variables in the whole water column (from which we used only temperature and salinity subsets closest to the bottom). Separate models were computed for the different sample localities (Fig. 1), water depths and time periods for $P$. jacobaeus (25-30 m, 2009-2013) and $G$. pilosa (10 m, 2011-2014).

\subsection{Sample collection}

Pecten jacobaeus specimens were collected by the commercial beam trawl type "Rapido" along the western coast of the Istrian peninsula (North Adriatic) in December 2013 and January 2014 (Fig. 1). Sampling was conducted within latitudes $45^{\circ} 08^{\prime} 57.76^{\prime \prime}-45^{\circ} 23^{\prime} 07.55^{\prime \prime} \mathrm{N}$, and longitudes $13^{\circ} 17^{\prime} 04.99^{\prime \prime}-13^{\circ} 54^{\prime} 04.07^{\prime \prime} \mathrm{E}$ at depths between 25 and $30 \mathrm{~m}$ and haul duration varied between 20 and $30 \mathrm{~min}$. Specimens were transported to the laboratory, soft tissues carefully removed, and shells washed and stored dry at the Institute of Oceanography and Fisheries in Split.

Isotope-ratio analyses focused on three shells collected in December 2013 (PJ12-5, PJ12-8 and PJ12-16) and one shell collected in January 2014 (PJ1-3). Shell length (anterior-posterior axis) and height (dorsoventral axis) of each scallop were measured with vernier calipers to the nearest $0.1 \mathrm{~mm}$. Prior to laboratory analysis, left valves were gently brushed to remove most of the epibionts as well as sediment trapped between striae, and washed in a $10 \mathrm{vol} \%$ acetic acid bath for $30 \mathrm{~s}$ followed by rinsing in water (Thébault and Chauvaud, 2013).

Glycymeris pilosa samples were collected by SCUBA diver in March 2016 at $10-11 \mathrm{~m}$ depth from a coastal locality in the North Adriatic Sea $\left(44^{\circ} 59^{\prime} 7.47^{\prime \prime} \mathrm{N}, 13^{\circ} 44^{\prime} 19.22^{\prime \prime} \mathrm{E}\right.$; WGS84). Upon collection specimens were frozen and transported to our laboratory where they were thawed, soft tissues carefully removed, and shells washed and air dried. Three shells of similar size were selected for analyses (S3P67, S3P91 and 


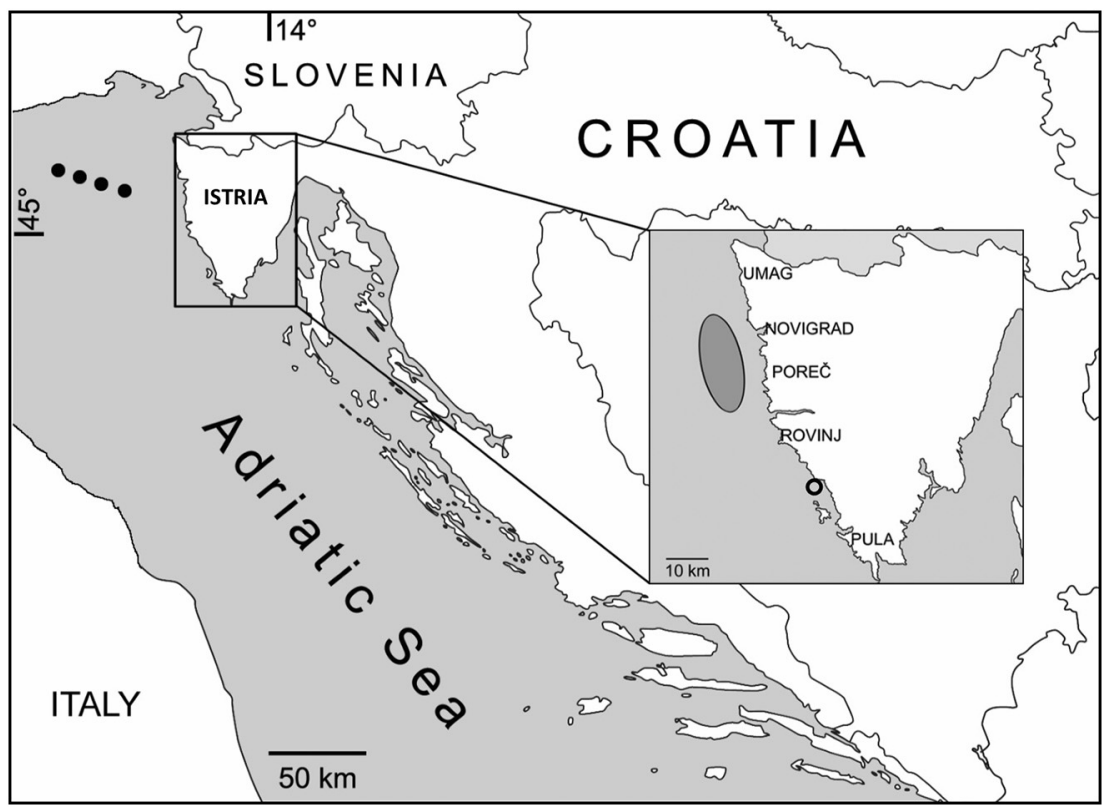

Fig. 1. Map of the study area indicating the location at which Pecten jacobaeus was collected by the commercial fishing beam trawl (dark grey) and the SCUBA diving locality at which Glycymeris pilosa was collected (black empty circle). The four black filled dots off Istria Peninsula represent the stations where Stenni et al. (1995) sampled water for $\delta^{18} \mathrm{O}_{\mathrm{w} \text {-SMOw }}$ and salinity analyses.

S3P106). Prior to collection of samples for stable-isotope ratio analysis, the periostracum was physically removed with grinding paper.

\subsection{Stable isotope analysis}

Samples for the shell calcium carbonate oxygen $\left(\delta^{18} \mathrm{O}\right)$ and carbon $\left(\delta^{13} \mathrm{C}\right)$ isotope-ratio analysis were collected by milling narrow sample swaths from the shells by hand under a stereo microscope using a DREMEL Fortiflex drill equipped with a $300 \mu \mathrm{m}$ tungsten carbide drill bit. Estimating milling depth was $\sim 100 \mu \mathrm{m}$. For $P$. jacobaeus, shallow milling was completed parallel to the growth striae, each sample extending over 1-3 striae (Fig. 2). In total, 308 samples were collected: 61 from shell PJ12-5, 79 from shell PJ12-8, 68 from shell PJ12-16 and 100 from shell PJ1-3. Shells were photographed and distances between samples were measured using Image Pro Premier software. For G. pilosa, shallow milling was done parallel to the growth lines covering two growth increments, as well as several samples before and after these two growth increments. Growth increments were chosen on the basis of their width in order to obtain a sufficient number of samples $(>9)$ per growth increment. Mean distance between samples was $\sim 193 \pm 40 \mu \mathrm{m}$. In total 93 samples were analyzed: 29 from shell S3P67, 35 from shell S3P91 and 29 from shell S3P106. During milling, detailed notes were taken on position of samples in relation to growth lines visible on the external shell surface.

Isotope-ratio analyses was performed at the University of Mainz, Germany, on a Thermo Finnigan MAT 253 continuous flow - isotope ratio mass spectrometer, equipped with a GasBench II. Samples were measured against an in-house Carrara marble $\left(\delta^{18} \mathrm{O}=+2.01 \%\right.$; $\delta^{13} \mathrm{C}=-1.91 \% 0$ ) calibrated against the international isotopic reference standard NBS-19. Results are expressed as parts per thousand with respect to the Vienna Pee Dee Belemnite standard (\%o V-PDB). Long-term (1.5 years) reproducibility ( $=$ accuracy, 1 sigma) of the mass spectrometer is $0.04 \%$ for $\delta^{18} \mathrm{O}$ and $0.03 \%$ for $\delta^{13} \mathrm{C}$ based on 421 blind measurements of NBS-19. The average 1 sigma internal precision error (eight injections per sample) is $0.04 \%$ for $\delta^{18} \mathrm{O}$ and $0.03 \%$ for $\delta^{13} \mathrm{C}$.

To enable temporal alignment of obtained $\delta^{18} \mathrm{O}_{\text {shell }}$ values, daily modeled seawater salinity and temperature data were used for reconstructing theoretical variations of $\delta^{18} \mathrm{O}_{\text {shell. }}$ Kim and O'Neil (1997) equation for calcite was applied to the $P$. jacobaeus dataset:

$1000 \ln \alpha_{\text {calcite-water }}=18.03\left(10^{3} \mathrm{~T}^{-1}\right)-32.42$

For the aragonite G. pilosa dataset the Kim et al. (2007) equation of was applied:

$1000 \ln \alpha_{\text {aragonite-water }}=17.88\left(10^{3} \mathrm{~T}^{-1}\right)-31.14$

Because $\delta^{18} \mathrm{O}_{\mathrm{w} \text {-SMow }}$ of the water was not monitored over the lifespan of the studied specimens, we reconstructed $\delta^{18} \mathrm{O}_{\mathrm{w} \text {-SMow }}$ values from modeled salinity data (S) using the equation derived from Stenni et al. (1995) data for $\delta^{18} \mathrm{O}_{\mathrm{w}-\mathrm{SMOw}}$ and salinity at transect B (black filled dots on Fig. 1):

$\delta^{18} \mathrm{O}_{\mathrm{W}-\mathrm{SMOW}}=0.366^{*} \mathrm{~S}-12.568\left(\mathrm{r}^{2}=0.964\right)$

To convert $\delta^{18} \mathrm{O}$ values from the V-PDB to V-SMOW (Vienna Standard Mean Ocean Water) scale, and vice versa, the equation of Coplen et al. (1983) was used. $\delta^{13} C_{\text {shell }}$ values for $P$. jacobaeus were detrended, as previously done for Pecten maximus by Chauvaud et al. (2011). Presence of ontogenic trends in $\delta^{13} C_{\text {shell }}$ values can mask the seasonal signal of this parameter and its detrending enables comparison with $\delta^{18} \mathrm{O}_{\text {shell }}$ values (Chauvaud et al., 2011). The least-squares fit of a straight line was calculated separately for each analyzed individual. Subsequently, these values were subtracted from measured $\delta^{13} \mathrm{C}_{\text {shell }}$ data. The residual time-series is referred to as $\delta^{13} \mathrm{C}_{\text {shell det. }}$ Spearman correlation was applied for testing relationship between $\delta^{18} \mathrm{O}_{\text {shell }}$ and $\delta^{13} \mathrm{C}_{\text {shell }}$.

Temporal aligning of measured $\delta^{18} \mathrm{O}_{\text {shell }}$ values was conducted manually in Excel by assigning each data point calendar date that placed that measured data point on graph closest to modeled $\delta^{18} \mathrm{O}_{\text {shell }}$ values. Final graphs were prepared in Sigma Plot 13.0 software.

\section{Results}

\subsection{Environmental variables}

For the area where $P$. jacobaeus specimens were collected, the modeled values for seawater bottom temperature $(25-30 \mathrm{~m})$ showed pronounced seasonal patterns, with minimum values $\left(\sim 10{ }^{\circ} \mathrm{C}\right.$ or lower $)$ occurring between January and April, and maximum values $\left(\sim 19^{\circ} \mathrm{C}\right.$ or higher) from July to October (Fig. 3). The overall lowest and highest monthly temperatures of $7.8^{\circ} \mathrm{C}$ and $20.6{ }^{\circ} \mathrm{C}$ occurred in March 2012 and October 2009, respectively. Modeled monthly values of bottom salinity ranged from 37.0 (November 2013) to 38.4 (February 2013). Between 2009 and 2013, mean salinity \pm one standard deviation was $37.9 \pm 0.3$. Most variable intra-annual values were noted during 2013, when the lowest values were also obtained through the ROMS 


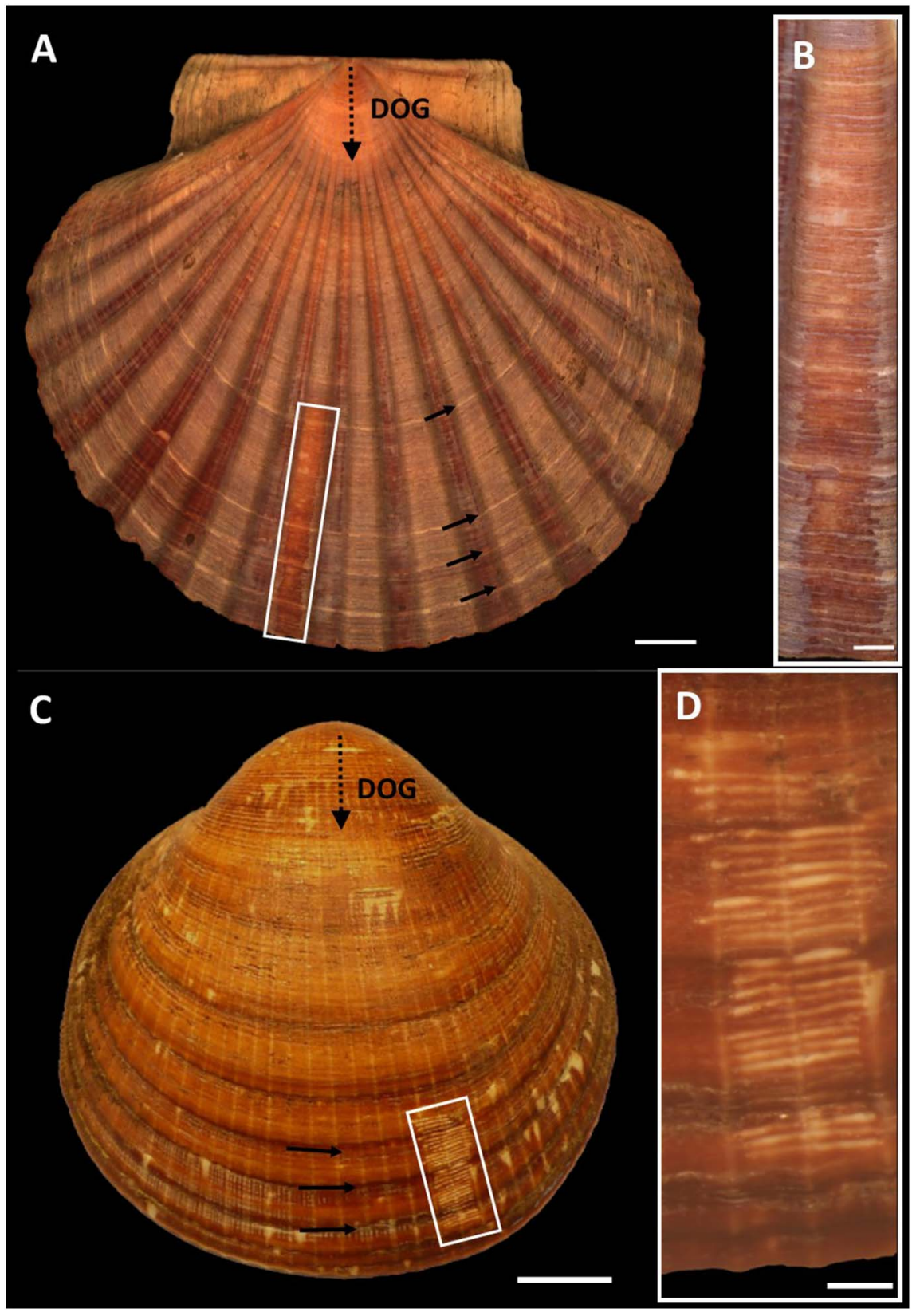

Fig. 2. A. Left valve of Pecten jacobaeus shell PJ 12-8 showing bright annual growth rings (black arrows) and milling swaths (within white rectangle) for isotope-ratio analyses. B. Close-up of milling swaths on the surface of $P$. jacobaeus. C. Glycymeris pilosa shell S3P106 showing dark growth rings (black arrows) and milling swaths (within white rectangle) for isotope analysis. D. Close-up of milling swaths on the surface of $G$. pilosa. Direction of shell growth (DOG) indicated with dashed arrows. Scale bars represent $1 \mathrm{~cm}$ in $\mathrm{A}$ and $\mathrm{C}$, and $2 \mathrm{~mm}$ in $\mathrm{B}$ and $\mathrm{D}$. simulation for the second half of the year. Overall, the time interval between October and December was characterized by higher variations in bottom salinity.

At the shallow coastal locality (10-11 m depth) where G. pilosa was collected, modeled values for seawater bottom temperature ranged from $7.7^{\circ} \mathrm{C}$ (February 2012) to $25.7^{\circ} \mathrm{C}$ (August 2014). Annual minimum values $\left(\sim 13{ }^{\circ} \mathrm{C}\right.$ or lower) occurred from January to April, while annual maximum values $\left(\sim 20^{\circ} \mathrm{C}\right.$ or higher) were characteristic for the months of June to September. Large sweater temperature variations sometimes occurred within days. Furthermore, pronounced variations in lowest modeled sweater temperatures between years are clearly evident, e.g., high winter seawater temperatures corresponding to the beginning of year 2014. Between the beginning of year 2011 and June 2014 salinity values ranged between 35.9 (September 2013) and 38.5 (April 2012), with an average of $37.7 \pm 0.4$ (1 SD). Modeled salinity showed considerable variability within and between years. With the exception of 2011, higher salinity was observed during the first half of the calendar year (January to June), whereas lower and more variable salinities were characteristic for the July to November period.

Modeled temperatures for two studied areas clearly show that temperature maxima were lower in deeper water (for P. jacobaeus) and occurred later during the year (Fig. 3C). Winter temperature minima were very similar between two studied locations as the water column is well mixed during this season. Salinity was in general lower in shallower water and more variable on daily to weekly time scales.

\subsection{Pecten jacobaeus shell geochemistry}

Shell lengths of analyzed $P$. jacobaeus ranged from $98.3 \mathrm{~mm}$ (PJ1216) to $116.5 \mathrm{~mm}$ (PJ12-8). Shells PJ1-3 and PJ12-5 had intermediate lengths of 113.0 and $116.0 \mathrm{~mm}$, respectively. The $\delta^{13} \mathrm{C}_{\text {shell calcite values }}$ of $P$. jacobaeus shells ranged from -1.64 to $+0.40 \%$ \% $(\mathrm{N}=308$, $\bar{x}=-0.52 \pm 0.45 \%$, $1 \mathrm{SD}$ ), and showed an ontogenetic decline as shell height increased (Fig. 4). The $\delta^{18} \mathrm{O}_{\text {shell }}$ calcite values ranged from +0.01 to $+3.08 \%$ o $(\mathrm{N}=308, \bar{x}=1.40 \pm 0.64 \%$, Fig. 5$)$. Observed

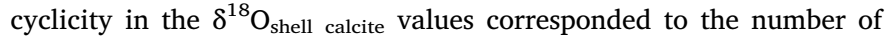
lightly colored growth rings observed on the external shell surface of $P$. 


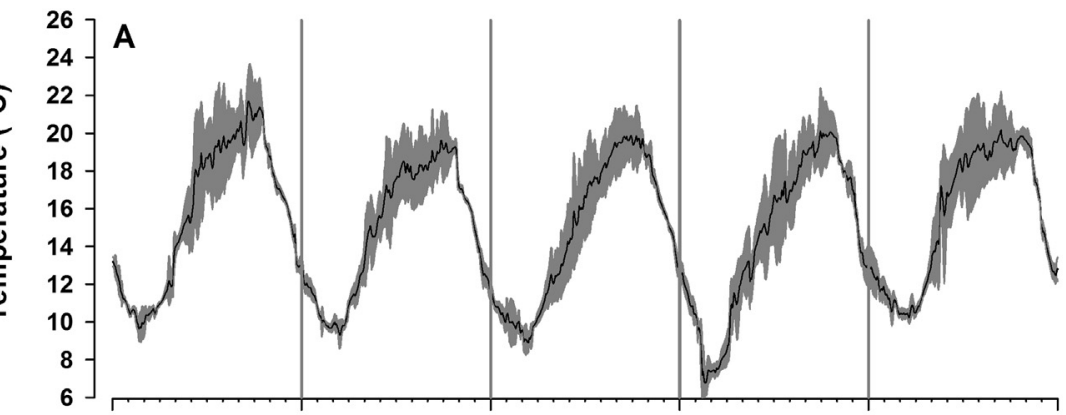

Fig. 3. Modeled seawater temperature (A) and salinity (B) curves for the Pecten jacobaeus sampling area. Black lines indicate daily average values, grey areas \pm 2 SD. Modeled temperature (C) and salinity curves (D) for the sampling sites of $P$. jacobaeus (black, sampling depth 25-30 m) and Glycymeris pilosa (dark grey, sampling depth $10-11 \mathrm{~m})$.
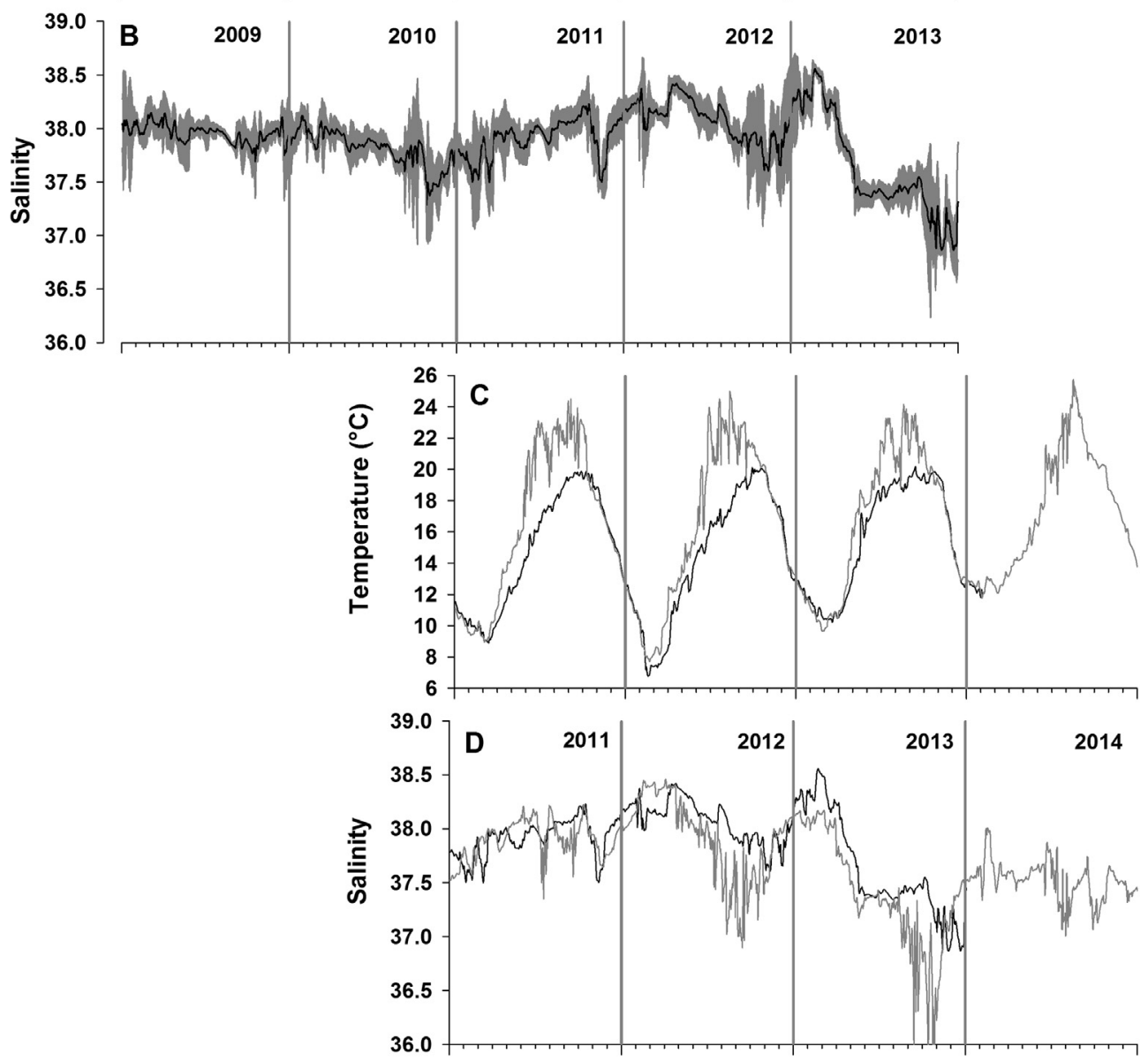

jacobaeus, thereby validating the annual periodicity of these bands. Stable isotope values corresponded to the time interval from 2009 to 2013. Detrending of $\delta^{13} \mathrm{C}_{\text {shell }}$ values enabled the analysis of seasonal variations and comparison of $\delta^{13} \mathrm{C}_{\text {shell det }}$ and $\delta^{18} \mathrm{O}_{\text {shell calcite }}$ values (Fig. 5). A certain degree of cyclicity was observed in $\delta^{13} \mathrm{C}_{\text {shell det }}$ with higher values coinciding with the highest $\delta^{18} \mathrm{O}_{\text {shell calcite values (coldest }}$ part) of each year, whereas lower $\delta^{13} \mathrm{C}_{\text {shell det }}$ values coincided with lower $\delta^{18} \mathrm{O}_{\text {shell calcite }}$ values (warmerest part of the year). There was a statistically significant, albeit weak, positive correlation between

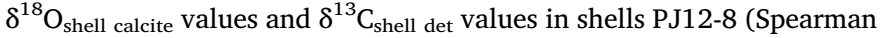
$\left.\mathrm{r}^{2}=0.40, \mathrm{p}<0.001\right)$, PJ12-16 $\left(\mathrm{r}^{2}=0.80, \mathrm{p}<0.001\right)$, and PJ1-3 $\left(\mathrm{r}^{2}=0.43, \mathrm{p}<0.001\right)$, but no such significant correlation occurred in shell PJ12-5 $\left(\mathrm{r}^{2}=0.16, \mathrm{p}=0.211\right)$.

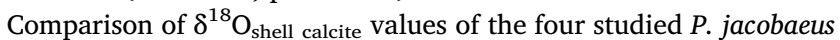
shells and $\delta^{18} \mathrm{O}_{\text {shell calcite values reconstructed on the basis of the ROMS }}$ output and the local freshwater mixing line are shown in Fig. 6. Major growth rings visible on the external shell surface of the left valve coincided with $\delta^{18} \mathrm{O}_{\text {shell calcite }}$ minima. This suggests that cessation and/or slowdown of shell growth occurred during the warmest part of the year. In all shells, growth resumes in December, at the latest. In most years, no or very little shell growth occurred during a period of almost 5 months, between July and November. Some shell growth variations were observed between years and specimens, and it appears that the shell growth slowdown periods were absent or shorter during early ontogeny (Fig. 6C). Besides seasonal shell growth cessation, there were time intervals of faster growth, as indicated by shell portions during which reconstructed temperatures barely changed. Shells appear to have grown faster during the periods December-January and April--

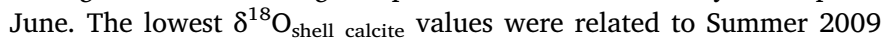
(PJ1-3). Three of the studied shells showed $\delta^{18} \mathrm{O}_{\text {shell }}$ calcite maxima of $\sim 3 \%$ during early 2012 , which is consistent with the lowest modeled temperature for this period.

\subsection{Glycymeris pilosa shell geochemistry}

Lengths of analyzed G. pilosa shells were 56.4 (S3P67), 58.9 (S3P91) and $58.6 \mathrm{~mm}$ (S3P106). In case of this species, $\delta^{13} \mathrm{C}_{\text {shell aragonite values }}$ for the three studied specimens ranged from +0.80 to $+1.97 \% 0$ $(N=93, \bar{x}=+1.33 \pm 0.23 \%)$, whereas the $\delta^{18} \mathrm{O}_{\text {shell aragonite }}$ values ranged from -0.36 to $+2.64 \%$ o $(\mathrm{N}=93, \bar{x}=-1.04 \pm 0.81 \% 0)$ 

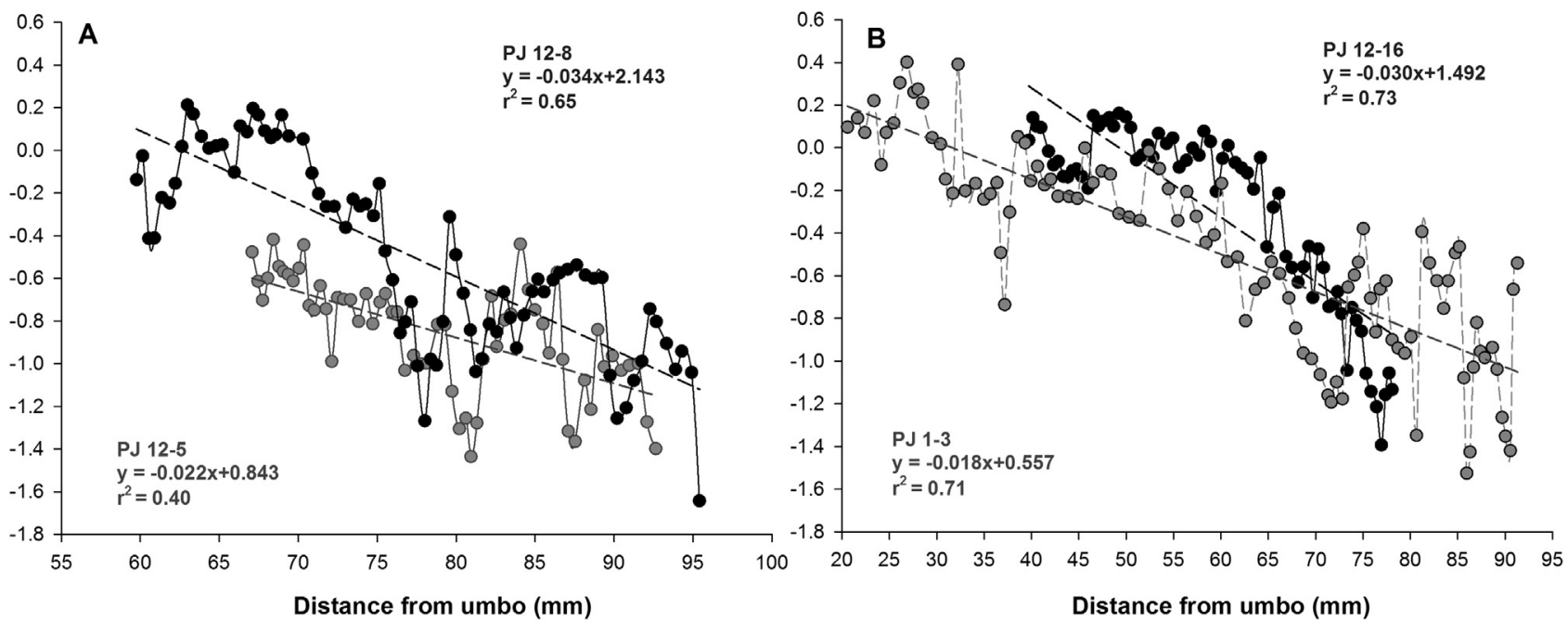

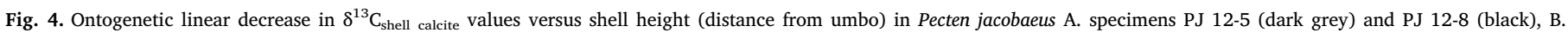
Specimens PJ 12-16 (black) and PJ 1-3 (dark grey). Linear regression lines, equations and determination coefficients shown in corresponding graphs.

(Fig. 7). Observed $\delta^{18} \mathrm{O}_{\text {shell aragonite }}$ values correspond to the number of increments on the external shell surface confirming that growth lines were formed annually and measured values correspond to the time interval of Spring 2011 to Winter 2013/2014. A statistically significant, albeit weak, positive correlation was found between $\delta^{13} \mathrm{C}_{\text {shell aragonite }}$

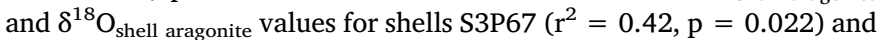
S3P106 $\left(r^{2}=0.41, p=0.002\right)$. There was no significant relationship between these two parameters in case of shell S3P91 $\left(r^{2}=-0.23\right.$, $\mathrm{p}=0.188$ ).

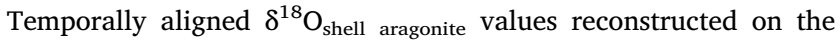
basis of the ROMS output and the local freshwater mixing line, as well as $\delta^{18} \mathrm{O}_{\text {shell aragonite }}$ values of the three studied $G$. pilosa shells, are shown in Fig. 8. Growth lines coincided with $\delta^{18} \mathrm{O}_{\text {shell aragonite minima or }}$ periods when values started to increase ( $\sim$ September). According to these data, G. pilosa did not show a pronounced shell growth slowdown or cessation during the summer period. Highest reconstructed $\delta^{18} \mathrm{O}_{\text {shell }}$ aragonite values were $3.37 \%$ o (February 20th 2012), which is $0.73 \%$ higher than the highest measured $\delta^{18} \mathrm{O}_{\text {shell aragonite value }(2.64 \% \text {, spe- }}$ cimen S3P67), indicating that shell growth slowed down or was halted during the coldest period of the year. Specimens S3P91 and S3P106 had

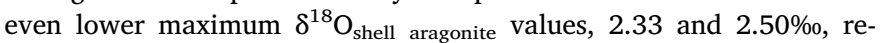
spectively. Based on these values, shells did not grow between January and March, or even longer. Temporal distances between measured $\delta^{18} \mathrm{O}_{\text {shell aragonite }}$ values indicate fastest shell growth occurred during October-November period, i.e., after the growth line formation. Seasonal differences in growth slowdown/cessation between the two studied species are evident from the data presented in Fig. 9. Whereas $G$. pilosa slowed shell growth during coldest part of the year, shell slowdown/cessation in P. jacobaeus occurred during warmest part of the year.

\section{Discussion}

\subsection{Periodicity of growth line formation and environmental conditions}

Strong inter-annual variations in $\delta^{18} \mathrm{O}_{\text {shell }}$ values of both studied bivalve species, $P$. jacobaeus and G. pilosa, as well as reconstructed and modeled seawater temperature and salinity values were observed.

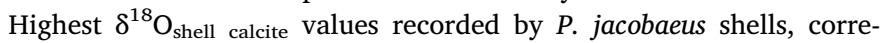
sponding to lowest seawater temperatures, occurred during February 2012. This coincided with extreme cooling of seawater and dense water formation in the Adriatic Sea (Janeković et al., 2014). Unlike P. maximus from the Atlantic which forms winter growth lines (Chauvaud et al., 1998, 2005, 2012; Owen et al., 2002), P. jacobaeus from the
North Adriatic seem to be able to deposit shell even at lowest winter seawater temperatures. It is interesting to note that seawater temperatures lower than $8{ }^{\circ} \mathrm{C}$, as those that occurred during the extreme cold event in February 2012, are extremely rare. Despite variations between years and specimens, this study clearly indicate that a $P$. jacobaeus shell growth slowdown and/or cessation occurred during the warmest part of the year.

Unlike $P$. jacobaeus, this study clearly indicates that $G$. pilosa cannot be used to reconstruct seasonal seawater temperature minima. Highest

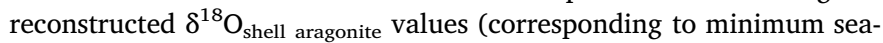
water temperatures) were significantly higher than $\delta^{18} \mathrm{O}_{\text {shell }}$ aragonite values obtained from the shell, indicating a slowdown/cessation of shell growth of $G$. pilosa from the North Adriatic during winter at seawater temperatures below $\sim 12{ }^{\circ} \mathrm{C}$. The same was found for a related species, Glycymeris bimaculata, from two localities in the eastern Adriatic - Pag Bay and Cetina river estuary (Purroy Albet, 2017). According to this study, G. bimaculata did not deposit new shell between January and April when seawater temperatures dropped below $\sim 12{ }^{\circ} \mathrm{C}$ in Pag bay and below $\sim 14^{\circ} \mathrm{C}$ in Cetina river estuary. Walliser et al. (2015) evaluated the potential of fossil bivalve Glycymeris planicostalis for highresolution reconstructions of seawater temperatures during the Early Oligocene (30 Ma) and found that shells grew uninterruptedly and have therefore, in their opinion, recorded the entire seasonal seawater temperature range at that time. Certain caution is needed when applying these findings to other species and locations, since Early Oligocene sweater parameters are not readily available. However, seawater temperature values reconstructed from these fossils ranged from 12.3 to $22.0^{\circ} \mathrm{C}$, i.e., lowest winter temperature exceeded the shutdown temperature of modern glycymerids in the Adriatic Sea. Caution needs to be applied when using G. planicostalis as a seawater temperature archive in deep time, because shells may have stopped growing below the lower seawater temperature threshold of $12{ }^{\circ} \mathrm{C}$ observed in recent glycymerids. A careful analysis of subannual shell growth patterns is advised prior to interpreting seawater temperature data of fossil bivalves. A growth slowdown below $12{ }^{\circ} \mathrm{C}$ has also been observed in G. glycymeris from Brittany, northwest France (Royer et al., 2013).

All studies cited in the paragraph above indicate the high potential of glycymerids for the reconstruction of summer seawater temperatures. In G. pilosa from the North Adriatic the annual growth line is formed in September, i.e. at the end of summer, but there was no pronounced slowdown in shell growth during the warm season of the

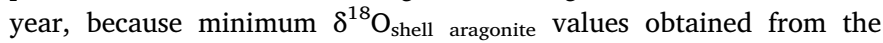
studied shells coincided well with the lowest reconstructed $\delta^{18} \mathrm{O}_{\text {shell }}$ aragonite values. 


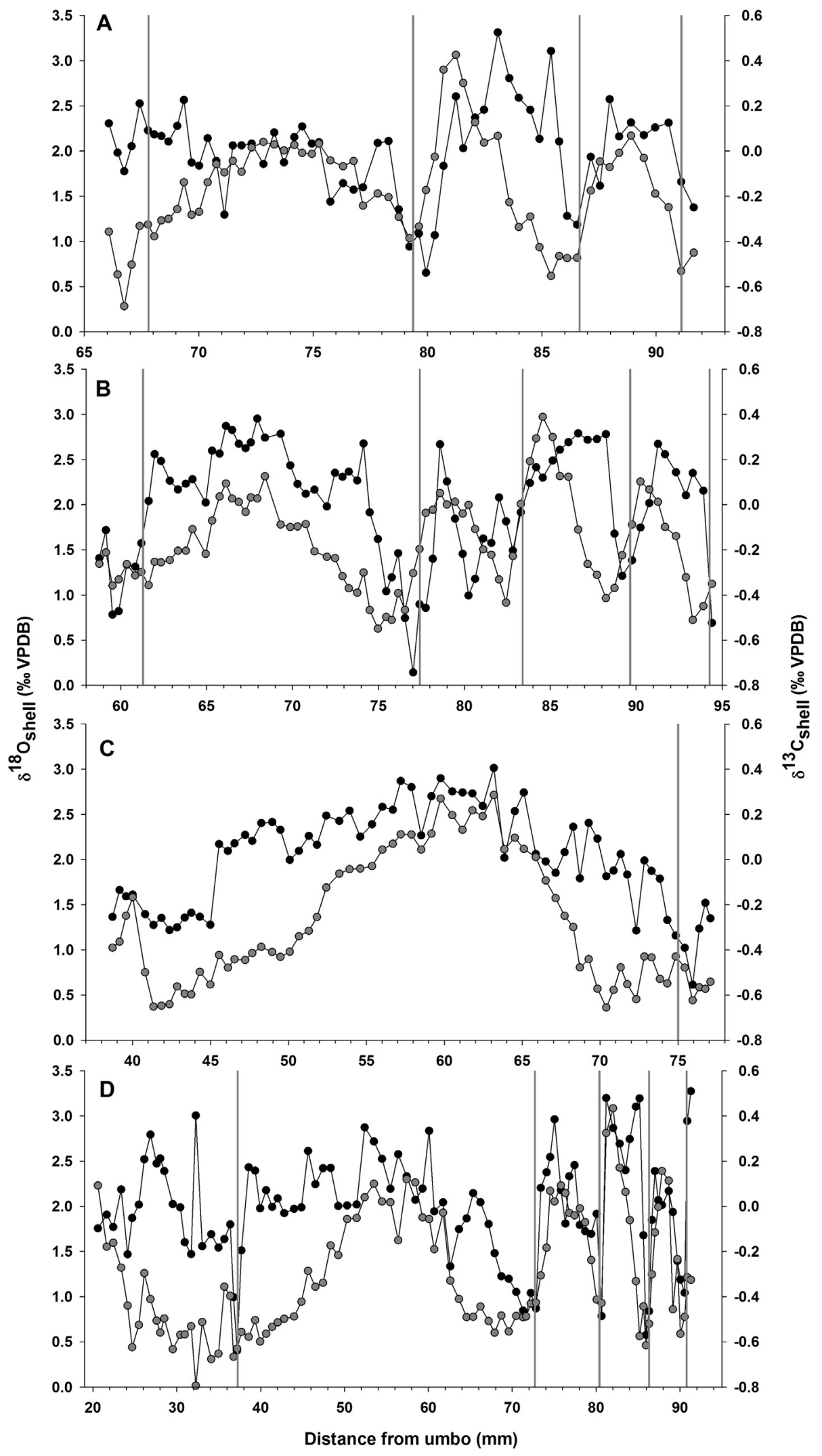

Fig. 5. Relationship between $\delta^{18} \mathrm{O}_{\text {shell }}$ alcite $\left(\mathrm{Y}_{1}\right.$ axis, dark grey) vs. $\delta^{13} \mathrm{C}_{\text {shell det }}\left(\mathrm{Y}_{2}\right.$ axis, black) for the four studied Pecten jacobaeus shells. A. PJ 12-5, B. PJ 12-8, C. PJ 12-16, D. PJ 1-3. Vertical bars identify annual growth lines observed on the outer shell surface.

Other factors besides seawater temperature can also influence shell growth rate and growth line formation. According to a recent experimental study on gaping activity of long lived bivalve Arctica islandica conducted in the Northern Norway, gaping activity was related to interaction of several environmental variables including Chlorophyll $a$, temperature and photoperiod (Ballestra-Artero et al., 2017). In an earlier paper, Witbaard et al. (2003) demonstrated that A. islandica growth in the northern North Sea is mainly influenced by the abundance of copepods. According to this study, copepods intercept downward flux of food particles what might lead to depression of shell 


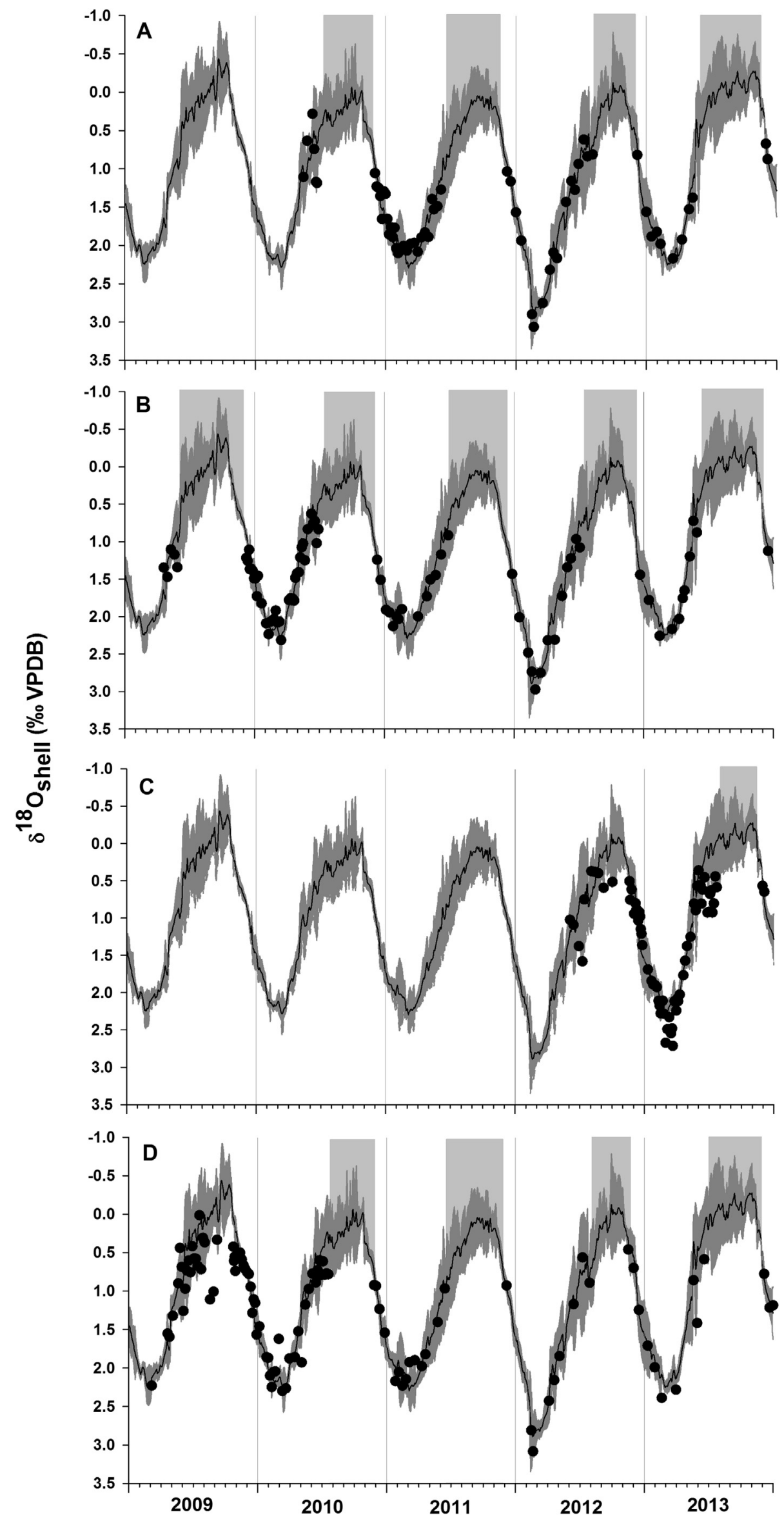

Fig. 6. Temporally aligned modeled $\delta^{18} \mathrm{O}_{\text {shell calcite }}$ values (black line $=$ daily averages, grey areas $\pm 2 \mathrm{SD}$ ) and measured $\delta^{18} \mathrm{O}_{\text {shell calcite }}$ values of Pecten jacobaeus shells (inverted scale). Missing reconstructed data denote slowdown or cessation of shell growth (grey shading). Vertical grey lines indicate calendar years. A. PJ 12-5, B. PJ 12-8, C. PJ 12-16, D. PJ 1-3. 

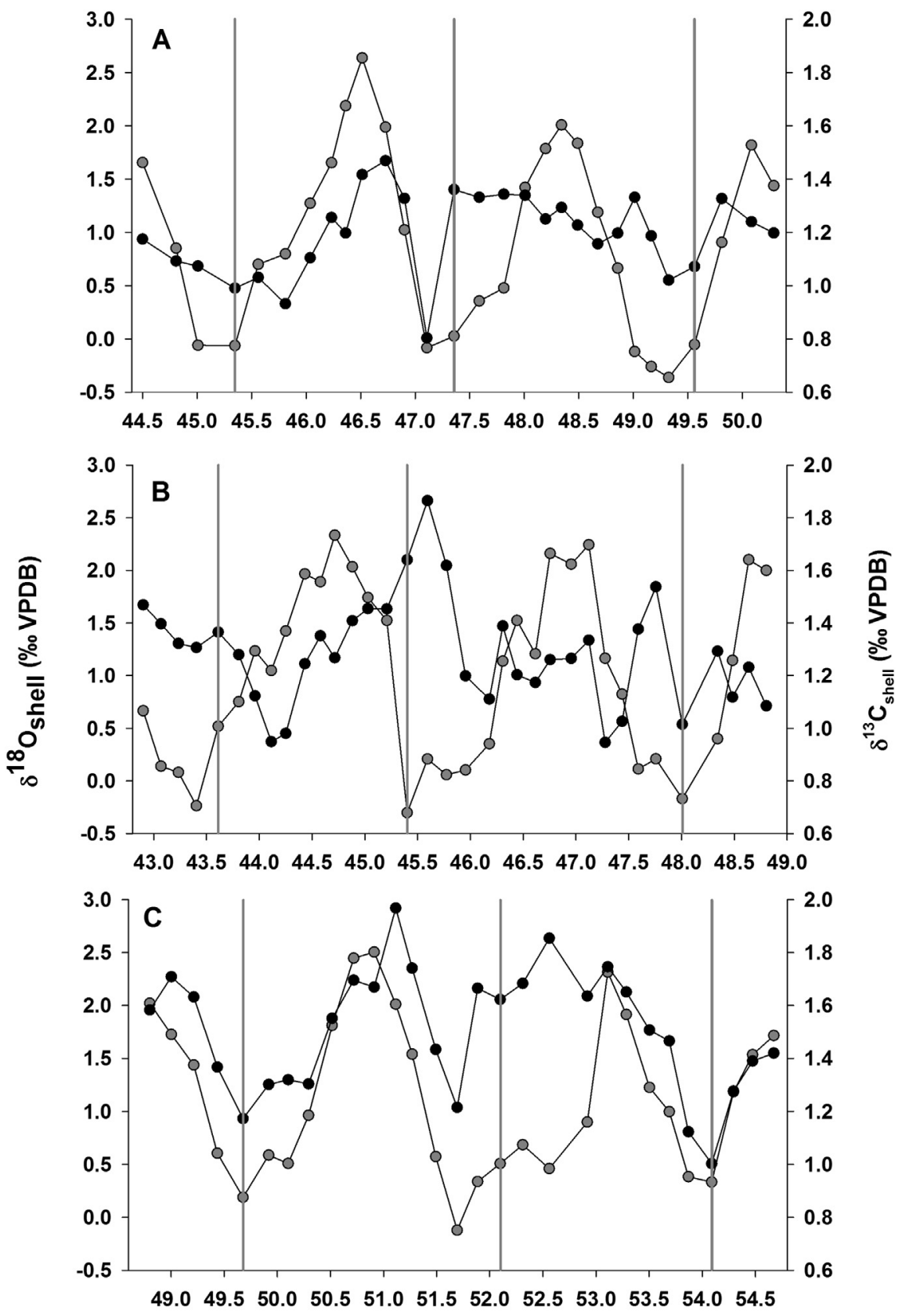

Fig. 7. Relationship between $\delta^{18} \mathrm{O}_{\text {shell aragonite }}\left(\mathrm{Y}_{1}\right.$ axis, grey) vs. $\delta^{13} \mathrm{C}_{\text {shell aragonite }}\left(\mathrm{Y}_{2}\right.$ axis, black) for three studied Glycymeris pilosa shells. A. S3P67, B. S3P91, C. S3P106. Vertical bars identify annual growth lines observed on the outer shell surface.

\section{Distance from umbo $(\mathrm{mm})$}

growth due to food shortage. An opposite relationship was reported by Wanamaker et al. (2009) in the western Gulf of Maine, were a significant positive correlation was determined between shell growth of $A$. islandica and relative abundance of copepod Calanus finmarchicus, indicating complex and environmentally specific relationships.

It has been demonstrated for several bivalve species that survival, metabolism and shell growth are reduced when animals are exposed to concurrent low dissolved oxygen and low $\mathrm{pH}$ conditions (Gobler and Baumann, 2016). Gobler et al. (2014) analyzed the effects of hypoxia and acidification on early life stages of bivalves and found that shell growth was significantly reduced when both conditions occurred simultaneously. According to Djakovac et al. (2015), hypoxia events occurred frequently in the north Adriatic Sea between mid-summer and mid-fall. Low pH conditions occurred in the Gulf of Trieste (North Adriatic Sea) during August and September (Cantoni et al., 2012). Unfortunately, there is no sufficient data available to evaluate whether hypoxia is an annual event of similar intensity between years, since data collection efforts in the area vary between years. Mid-fall period coincided with the annual growth line formation of both species, possibly indicating that growth line is formed as a response to low DO and low $\mathrm{pH}$. Recent expansion of low oxygen zones in coastal ecosystems, a trend that may accelerate with climate warming (Gobler et al., 2014), will likely have negative effects on bivalve growth.

\subsection{Trends in $\delta^{13} C_{\text {shell }}$ and $\delta^{18} O_{\text {shell }}$ values}

An ontogenetic trend of $\delta^{13} \mathrm{C}_{\text {shell }}$ to lower values has previously been observed for many bivalve species (for review see McConnaughey and Gillikin, 2008). Examples of some recent studies include the great scallop, P. maximus from the Atlantic (Chauvaud et al., 2011), the thorny oyster, Spondylus gaederopus from the Mediterranean (Maier and Titschack, 2010) and the date shell, Lithophaga lithophaga from the 


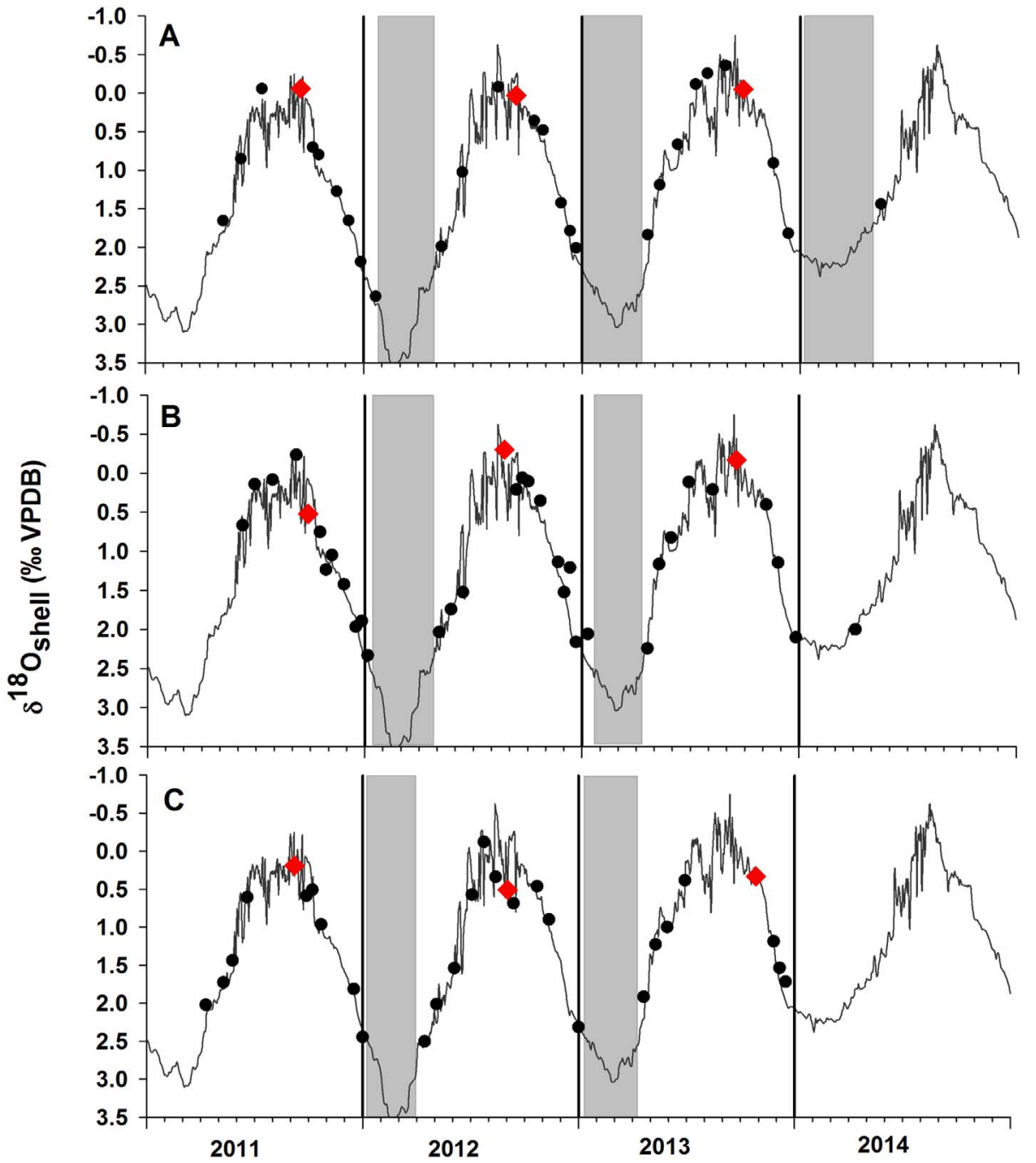

Fig. 8. Temporally aligned modeled $\delta^{18} \mathrm{O}_{\text {shell aragonite values }}$ and measured $\delta^{18} \mathrm{O}_{\text {shell aragonite values of Glycymeris pilosa }}$ shells (inverted scale). Absence of reconstructed data indicates slowdown or stop of shell growth. Vertical black lines indicate calendar years, red data points indicate position of growth lines, grey areas indicate periods of shell growth slowdown. A. S3P67, B. S3P91, C. S3P106. coastal middle Adriatic (Peharda et al., 2015). Observed decrease in $\delta^{13} \mathrm{C}_{\text {shell }}$ values with age might also be related to marine Suess effect, as was previously observed for Arctica islandica (Schöne et al., 2011). Presence of strong ontogenetic trends can mask the seasonal signal, and therefore, Chauvaud et al. (2011) suggested detrending $\delta^{13} \mathrm{C}_{\text {shell }}$ values of species that show age-related trends in order to enable an analysis of seasonal variations.

P. maximus from the Bay of Brest had lowest values of $\delta^{13} \mathrm{C}_{\text {shell det }}$ in late spring/early summer, most likely reflecting corresponding variations in food availability (Chauvaud et al., 2011). In our study, in $P$. jacobaeus, low $\delta^{13} \mathrm{C}_{\text {shell det }}$ values coincided with $\delta^{18} \mathrm{O}_{\text {shell }}$ values corresponding to spring. In case of G. pilosa, $\delta^{13} \mathrm{C}_{\text {shell }}$ values varied among specimens and between years, but in general lowest $\delta^{13} \mathrm{C}_{\text {shell det }}$ values occurred in the summer. Similar findings were reported for the thorny oyster, $S$. gaederopus from the Mediterranean Sea with lowest $\delta^{13} \mathrm{C}_{\text {shell }}$ values attained in May/June, whereas phytoplankton blooms regularly occurred in January/February (Maier and Titschack, 2010). Highest stable carbon isotope values in young Arctica islandica occurred during summer, i.e., during maximum primary productivity (Schöne et al., 2005). Due to observed inter-specimen variations in $\delta^{13} \mathrm{C}_{\text {shell values, }}$ future studies should analyze this parameter before it can be fully evaluated and applied for the reconstruction of environmental variability.

Changing relationships between $\delta^{13} \mathrm{C}_{\text {shell }}$ and $\delta^{18} \mathrm{O}_{\text {shell }}$ in coeval specimens from the same habitat have been noticed in previous studies and were interpreted at reflecting variable biological controls on the incorporation of carbon isotopes into the shell (Lorrain et al., 2004). In this study, such variations were observed for both studied bivalves, $P$. jacobaeus and G. pilosa. A statistically significant positive correlation between these two variables was observed in three out of four studied $P$. jacobaeus shells, and in two out of three studied $G$. pilosa specimens. Overall, $\delta^{13} \mathrm{C}_{\text {shell }}$ values for $G$. pilosa were significantly higher $(\bar{x}=$ $+1.33 \%$ ) than those for P. jacobaeus $(\bar{x}=-0.52 \%$; Mann Whiney test $\mathrm{z}=-14.62, \mathrm{p}<0.0001)$. It is interesting to note that $\delta^{13} \mathrm{C}_{\text {shell det }}$ values of $P$. jacobaeus in the present study ( -1.64 to $0.40 \%$ ) are lower than those measured by Chauvaud et al. (2011) in the closely related species $P$. maximus ( -0.94 to $1.89 \%$ ). Stable carbon isotope-ratio values of $G$. pilosa ( 0.80 to $1.97 \%$ ), however, were almost identical to those previously determined in $G$. bimaculata from the Pag bay, middle Adriatic Sea (0.81 to $2.03 \%$, Bušelić et al., 2015). Lower $\delta^{13} \mathrm{C}_{\text {shell }}$ values in $G$. bimaculata were recently obtained for shells collected from Pag bay and Cetina river estuary ( -0.52 to $1.77 \%$; Purroy Albet, 2017), indicating differences possibly related to site and year. Future studies should analyze carbon isotope-ratio values from same species across different sampling sites characterized by different environmental conditions, as well as from different species collected at the same size in order to gain a better understanding of $\delta^{13} \mathrm{C}_{\text {shell }}$ potential as an environmental proxy. Such studies should include detailed analysis of environmental variables.

\subsection{Chemical sclerochronology and bivalve ecology}

In order to fully understand these marine bivalve mollusk archives, future studies should address the ecology of the studied species including reproduction, feeding ecology and growth rate of soft tissues. 


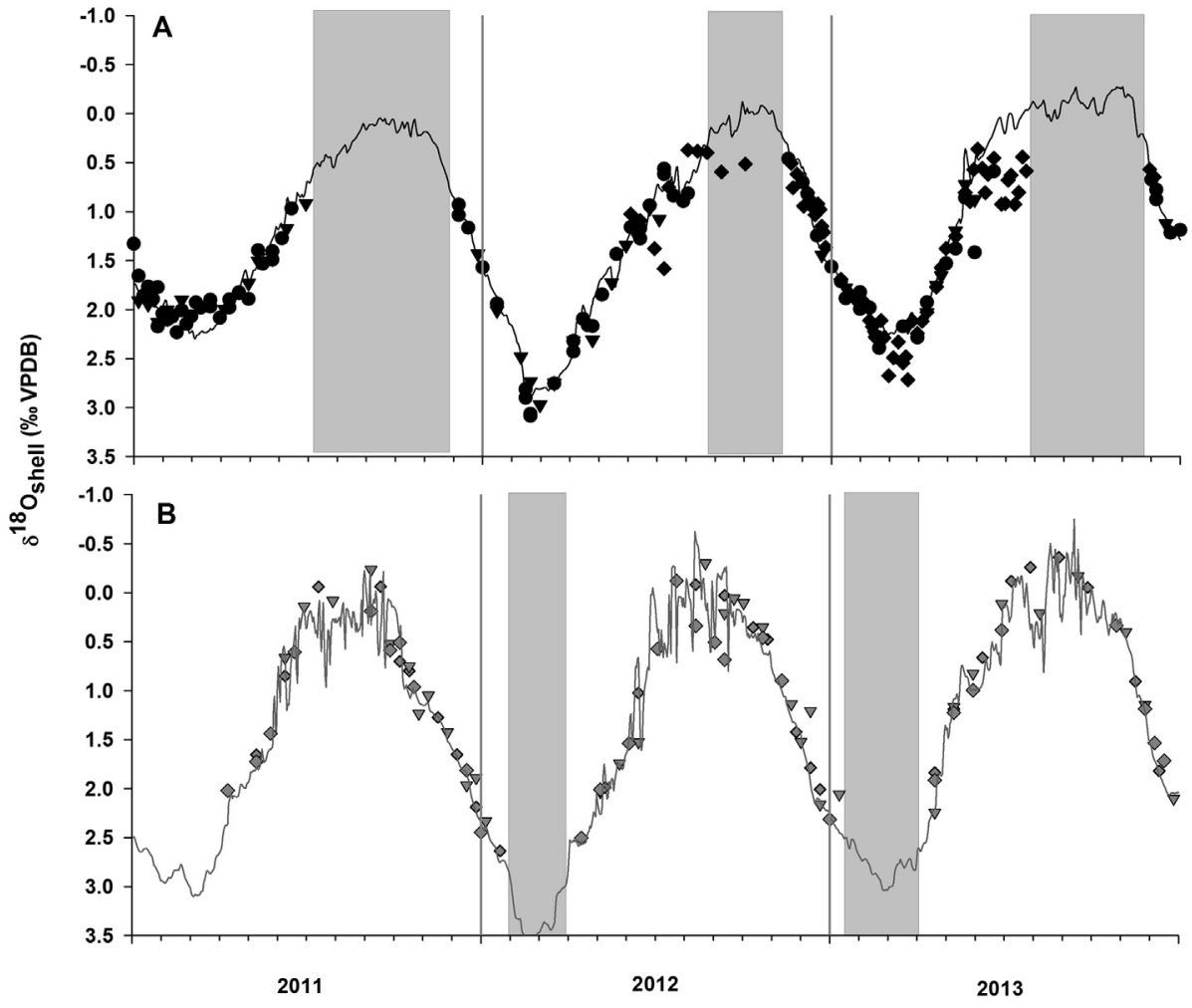

Fig. 9. Comparison between modeled $\delta^{18} \mathrm{O}_{\text {shell }}$ values (line) and temporally aligned $\delta^{18} \mathrm{O}_{\text {shell }}$ values (symbols). A. Pecten jacobaeus, B. Glycymeris pilosa. Different individuals shown in different symbols. Grey areas indicate periods of shell growth slowdown or cessation.
As yet, only reproduction data were published for a $P$. jacobaeus population from the Krka River estuary, middle Adriatic (Marguš et al., 1993). According to this study, the highest gonad index was attained in February followed by a strong decrease in April and May. Low gonad indices were observed during summer and minimum values in September. According to the recent work of Ezgeta-Balić (unpublished data), full gonads were developed in $P$. jacobaeus from the North Adriatic during January to April, and a decrease in gonad mass was observed in early May. In this study, shell growth was fastest between April and June indicating that $P$. jacobaeus redirected its energy resources to growth as soon as spawning was over. The main shell growth slowdown overlapped with the low gonad index, possibly indicating unfavorable environmental conditions. To date, there is no study on feeding ecology of this species. According to Chauvaud et al. (2011), seasonal and ontogenetic variations of $\delta^{13} \mathrm{C}_{\text {shell }}$ in P. maximus shells can be considered as a possible tool for ecophysiological studies, and the same potential for P. jacobaeus shells should be explored in future field and laboratory studies.

The reproductive cycle of Glycymeris pilosa was recently analyzed by Purroy Albet (2017) on specimens collected from the Pašman channel, middle Adriatic Sea. From October to December most gonads were inactive. Gametogenesis started in December and early and late active stages extended into June when $\sim 20 \%$ of the population had ripe gonads, while others had gonads that were in late stage of development. Spawning took place between July and October. There is no other study on the reproductive cycle of this species. Periods of inactive gonads found by Purroy Albet (2017) coincided with times of faster shell growth in the North Adriatic G. pilosa population. Furthermore, the winter shell growth slowdown coincided with the early and late development of gonads, indicating that during this period of the year $G$. pilosa was redirecting its energy resources to reproduction.

The only available data on G. pilosa feeding ecology are those for populations from Pag bay and Pašman channel, Middle Adriatic Sea (Purroy Albet, 2017). According to this study, significant differences in $\delta^{13} \mathrm{C}_{\text {digestive gland }}(\% 0), \delta^{15} \mathrm{~N}_{\text {digestive gland }}(\% 0)$ and the C:N molar ratio occurred between sites, with significantly higher values at Pašman.
Since these two sites are geographically positioned relatively closely $(\sim 50 \mathrm{~km})$, isotopic variations clearly indicate that results cannot be used to interpret the feeding ecology of populations at other sites. Therefore, future studies should analyze variations in feeding ecology of $G$. pilosa along latitudinal, longitudinal and environmental gradients in order to identify possible relationships between food supply and growth.

\section{Conclusions}

Seasonal shell formation rates vary between bivalve species. Growth slowdown of the Mediterranean scallop P. jacobaeus from the North Adriatic Sea occurred during summer, whereas the bittersweet clam $G$. pilosa from the same area grew at slowest rates, or not at all, during winter. Both species formed distinct annual growth lines in September to November period, indicating that other factors, besides seawater temperature, are important drivers of shell growth. Possible drivers include low dissolved oxygen concentration and low $\mathrm{pH}$ conditions that co-occur in the North Adriatic during late summer/early fall (Cantoni et al., 2012; Djakovac et al., 2015). It is hypothesized here that climate change-induced variations of these parameters could negatively influence shell growth, especially in the case of $P$. jacobaeus.

In relation to further sclerochronological research, G. pilosa is an important target species for studies looking at variations in annual growth increments in the Adriatic and Mediterranean Seas (Peharda et al., 2016). Since G. pilosa forms annual growth lines in September, the annual shell growth increment covers certain periods of two calendar years. This needs to be taken into account when shell chronologies are constructed and annual shell increment width data are compared to environmental data. Furthermore, due to its longevity and continuous growth during the warmest part of the year, G. pilosa is an interesting archive for the reconstruction of seawater temperatures during summer. 


\section{Acknowledgements}

Authors are grateful to Daria Ezgeta Balic and Dragan Švigir for help with collection of samples. Research has been supported by Croatian Science Foundation under the project SCOOL (IP-2014-09-5747). We would like to thank two anonymous reviewers and guest editor $\mathrm{Al}$ Wanamaker for their comments that greatly improved our manuscript.

\section{Funding}

Research has been supported by Croatian Science Foundation under the project SCOOL (IP-2014-09-5747).

\section{Appendix A. Supplementary data}

Supplementary data to this article can be found online at https:// doi.org/10.1016/j.chemgeo.2017.09.029.

\section{References}

Adloff, F., Somot, S., Sevault, F., Jordà, G., Aznar, R., Déqué, M., Herrmann, M., Marcos, M., Dubois, C., Padorno, E., Alvarez-Fanjul, E., Gomis, D., 2015. Mediterranean Sea response to climate change in an ensamble of twenty first century scenarios. Clim. Dyn. 45, 2775-2802.

Ballestra-Artero, I., Witbaard, R., Carroll, M.L., van der Meer, J., 2017. Environmental factors regulating gaping activity of the bivalve Arctica islandica in Northern Norway. Mar. Biol. 164, 16. http://dx.doi.org/10.1007/s00227-017-3144-7.

Black, B.A., Copenheaver, C.A., Frank, D.C., Stuckey, M.J., Kormanyos, R.E., 2009. Multiproxy reconstructions of the northeastern Pacific sea surface temperature data from trees and Pacific geoduck. Palaeogeogr. Palaeoclimatol. Palaeoecol. 278, 40-47.

Brocas, W.M., Reynolds, D.J., Butler, P.G., Richardson, C.A., Scourse, J.D., Ridgway, I.D., Ramsay, K., 2013. The dog cockle, Glycymeris glycymeris (L.), a new annually-resolved sclerochronological archive for the Irish Sea. Palaeogeogr. Palaeoclimatol. Palaeoecol. 373, 133-140.

Bušelić, I., Peharda, M., Reynolds, D.J., Butler, P.G., Román González, A., Ezgeta-Balić, D., Vilibić, I., Grbec, B., Hollyman, P., Richardson, C.A., 2015. Glycymeris bimaculata (Poli, 1795) - a new sclerochronological archive for the Mediterranean? J. Sea Res. 95, 139-148.

Butler, P.G., Schöne, B.R., 2017. New research in the methods and applications of sclerochronology. Palaeogeogr. Palaeoclimatol. Palaeoecol. 465 (Part B), 295-299.

Butler, P.G., Wanamaker Jr., A.D., Scourse, J.D., Richardson, C.A., Reynolds, D.J., 2013. Variability in marine climate on the North Icelandic Shelf in a 1357-year proxy archive based on growth increments in the bivalve Arctica islandica. Palaeogeogr. Palaeoclimatol. Palaeoecol. 373, 141-151.

Cantoni, C., Luchetta, A., Celio, M., Cozzi, S., Raicich, F., Catalano, G., 2012. Carbonate system variability in the Gulf of Trieste (North Adriatic Sea). Estuar. Coast. Shelf Sci. $115,51-62$.

Chauvaud, L., Thouzeau, G., Paulet, Y.-M., 1998. Effects of environmental factors on the daily growth rate of Pecten maximus juveniles in the Bay of Brest (France). J. Exp. Mar. Biol. Ecol. 227, 83-111.

Chauvaud, L., Lorrain, A., Dunbar, R.B., Paulet, Y.-M., Thouzeau, G., Jean, F., Guarini, J.M., Mucciarone, D., 2005. Shell of the Great scallop Pecten maximus as a high-frequency archive of paleoenvironmental changes. Geochem. Geophys. Geosyst. 6 (8), Q08001.

Chauvaud, L., Thébault, J., Clavier, J., Lorrain, A., Strand, Ø., 2011. What's hiding behind ontogenetic $\delta^{13} \mathrm{C}$ variations in mollusk shells? New insights from the Great Scallop (Pecten maximus). Estuar. Coasts 34, 211-220.

Chauvaud, L., Patry, Y., Jolivet, A., Cam, E., Le Goff, C., Strand, Ø., Charrier, G., Thébault, J., Lazure, P., Gotthard, K., Clavier, J., 2012. Variation in size and growth of the Great Scallop Pecten maximus along a latitudinal gradient. PLoS ONE 7 (5), e37717.

Chute, A.S., Wainright, S.C., Hard, D.R., 2012. Timing of shell ring formation and patterns of shell growh in the sea scallop Placopecten magellanicus based on stable oxygen isotopes. J. Shellfish Res. 31, 649-662.

Clodia database, 2015. Database of Fishery Data from Chioggia, Northern Adriatic Sea http://chioggia.scienze.unipd.it/Database landing.html.

Coplen, T.B., Kendall, C., Hopple, J., 1983. Comparison of stable isotope reference samples. Nature 302, 236-238.

Crippa, G., Angiolini, L., Bottini, C., Erba, E., Fellatti, F., Frigerio, C., Hennissen, J.A.I. Leng, M.J., Petrizzo, M.R., Raffi, I., Raineri, G., Stephenson, M.H., 2016. Seasonality fluctuations recoreded in fosiil bivalves during the early Pleistocene: Implications for climate change. Palaeogeogr. Palaeoclimatol. Palaeoecol. 446, 234-251.

Dare, P.J., Deith, M.R., 1990. Age determination of scallops, Pecten maximus (Linnaeus, 1758), using stable oxygen isotope analysis, with some implications for fisheries management in British waters. In: Shumway, S.E., Sandifer, P.A. (Eds.), An International Compendium of Scallop Biology and Culture. World Aquacult. Soc, Baton Rouge, pp. 118-133.

Djakovac, T., Supić, N., Bernardi, A.F., Degobbis, D., Giani, M., 2015. Mechanisms of hypoxia frequency changes in the northern Adriatic Sea during the period 1972-2012. J. Mar. Syst. 141, 179-189.

Epstein, S., Buchsbaum, R., Lowenstam, H.A., Urey, H.C., 1953. Revised carbonate-water isotopic temperature scale. Bull. Geol. Soc. Am. 64 (11), 1315-1326.

García-March, J.R., Surge, D., Lees, J.M., Kersting, D.K., 2011. Ecological information and water mass properties in the Mediterranean recorded by stable isotope ratios in Pinna nobilis shells. J. Geophys. Res. 116, G02009.

Gillikin, D.P., Lorrain, A., Bouillon, S., Willenz, P., Dehairs, F., 2006. Stable carbon isotopic composition of Mytilus edulis shells: relation to metabolism, salinity, $\delta^{13} \mathrm{C}_{\text {DIC }}$ and phytoplankton. Org. Geochem. 37, 1371-1382.

Giorgi, F., Lionello, P., 2008. Climate change projections for the Mediterranean region. Glob. Planet. Chang. 63, 90-104.

Gobler, C.J., Baumann, H., 2016. Hypoxia and acidification in ocean ecosystems: coupled dynamics and effects on marine life. Biol. Lett. 12, 20150976.

Gobler, C.J., DePasquale, E.L., Griffith, A.W., Baumann, H., 2014. Hypoxia and acidification have additive and synergistic negative effects on the growth, survival and metamorphosis of early life stage bivalves. PLoS ONE 9 (1), e83648.

Gröcke, D.R., Gillikin, D.P., 2008. Advances in mollusc sclerochronology and sclerochemistry: tools for understanding climate and environment. Geo-Mar. Lett. 28, $265-268$.

Grossman, E.L., Ku, T.-L., 1986. Oxygen and carbon isotope fractionation in biogenic aragonite: temperature effects. Chem. Geol. 59, 59-74.

Heilmayer, O., Brey, T., Chiantore, M., Cattaneo-Vietti, R., Arntz, W.E., 2003. Age and productivity of the Antarctic scallop (Adamussium colbecki) in the Ross Sea. J. Exp. Mar. Biol. Ecol. 288, 239-256.

Hickson, J.A., Johnson, A.L.A., Heaton, T.H.E., Balson, P.S., 1999. The shell of the queen scallop Aequipecten opercularis (L.) as a promising tool for palaeoenvironmental reconstruction: evidence and reasons for equilibrium stable-isotope incorporation. Palaeogeogr. Palaeoclimatol. Palaeoecol. 154, 325-337.

Janeković, I., Dutour Sikirić, M., Tomažić, I., Kuzmić, M., 2010. Hindcasting the Adriatic Sea surface temperature and salinity: A recent modeling experience. Geofizika 27 85-100.

Janeković, I., Mihanović, H., Vilibić, I., Tudor, M., 2014. Extreme cooling and dense water formation estimates in open and coastal regions of the Adriatic Sea during the winter of 2012. J. Geophys. Res. Oceans 119, 3200-3218.

Jolivet, A., Asplin, L., Strand, Ø., Thébault, J., Chauvaud, L., 2015. Costal upwelling in Norway recvorded in Great Scallop shells. Limnol. Oceanogr. 60, 1265-1275.

Kim, S.-T., O'Neil, J.R., 1997. Equilibrium and nonequilibrium oxygen isotope effects in synthetic carbonates. Geochim. Cosmochim. Acta 61, 3461-3475.

Kim, S.-T., O'Neil, J.R., Hillaire-Marcel, C., Mucci, A., 2007. Oxygen isotope fractionation between synthetic aragonite and water: Influence of temperature and $\mathrm{Mg}^{2+}$ concentration. Geochim. Cosmochim. Acta 71, 4704-4715.

Krantz, D.E., Jones, D.S., Williams, D.F., 1984. Growth rates of the sea scallop, Placopecten magellanicus, determined from the ${ }^{18} \mathrm{O} /{ }^{16} \mathrm{O}$ record in shell calcite. Biol. Bull. 167, $186-199$.

Lasta, M., Valero, J., Brey, T., Bremec, C., 2001. Zygochlamys patagonica (King and Broderip) beds on the Argentinian shelf. Part II: Population dynamics of $Z$. patagonica. Arch. Fish. Mar. Res. 49, 125-137.

Lorrain, A., Paulet, Y.-M., Chauvaud, L., Dunbar, R., Mucciarone, D., Fontugne, M., 2004 $\delta^{13} \mathrm{C}$ variation in scallop shells: Increasing metabolic carbon contribution with body size? Geochim. Cosmochim. Acta 68, 3509-3519.

Maier, E., Titschack, J., 2010. Spondylus gaederopus: a new Mediterranean climate archive - based on high-resolution oxygen and carbon isotope analysis. Palaeogeogr. Palaeoclimatol. Palaeoecol. 291, 228-238.

Marchais, V., Richard, J., Jolivet, A., Flye-Sainte-Marie, J., Thébault, J., Jean, F., Richard P., Paulet, Y.-M., Clavier, J., Chauvaud, L., 2015. Coupling experimental and fieldbased approaches to decipher carbon sources in the shell of the great scallop, Pecten maximus (L.). Geochim. Cosmochim. Acta 168, 58-69.

Marguš, D., Teskeredžić, E., Modrušan, Z., Hacmanjek, M., 1992. Rasprostranjenost, gustoća i starosna struktura populacija jakovske kapice (Pecten jacobaeus L.) i male kapice (Chlamys varia L.) u ušću rijeke Krke. Pomorski zbornik. 30. pp. 599-618.

Marguš, D., Teskeredžić, E., Teskeredžić, Z., Tomec, M., 1993. Reproductive cycle and monitoring of scallop larvae (Pecten jacobaeus L.) in plankton from the mouth of the River Krka. Ribarstvo 48, 43-54.

Mariotti, A., Pan, Y., Zeng, N., Alessandri, A., 2015. Long-term climate change in the Mediterranean region in the midst of decadal variability. Clim. Dyn. 44, 1437-1456.

Mattei, N., Pelizzato, M., 1996. A population study on three stocks of a commercial Adriatic pectinid (Pecten jacobaeus). Fish. Res. 26, 49-65.

Mazzoldi, C., Sambo, A., Riginellia, E., 2014. The Clodia database: a long time series of fishery data from the Adriatic Sea. Sci. Data 1, 140018.

McConnaughey, T.A., Gillikin, D.P., 2008. Carbon isotopes in mollusk shell carbonates. Geo-Mar. Lett. 28, 287-299.

Onofri, V., Marguš, D., 1995. Biologija jakovske kapice (Pecten jacobaeus L.) i mogućnost njezinog uzgoja u području otoka Mljeta. In: Durbešić, P., Benović, A. (Eds.), Priopćenje sa simpozija "Prirodne značajke i društvena valorizacija otoka Mljeta". Ekološke monografije 6, Zagrebpp. 555-562 (in Croatian)

Oschmann, W., 2009. Sclerochronology: editorial. Int. J. Earth Sci. 98, 1-2.

Owen, R., Richardson, C.A., Kennedy, H., 2002. The influence of shell growth rate on striae deposition in the scallop Pecten maximus. J. Mar. Biol. Assoc. U. K. 82, 621-623.

Peharda, M., Soldo, A., Pallaoro, A., Matić, S., Cetinić, P., 2003. Age and growth of the Mediterranean scallop Pecten jacobaeus (Linnaeus 1758) in the northern Adriatic Sea. J. Shellfish Res. 22, 639-642.

Peharda, M., Puljas, S., Chauvaud, L., Schöne, B.R., Ezgeta-Balić, D., Thébault, J., 2015 Growth and longevity of Lithophaga lithophaga: what can we learn from shell structure and stable isotope composition? Mar. Biol. 162, 1531-1540.

Peharda, M., Black, B.A., Purroy, A., Mihanović, H., 2016. The bivalve Glycymeris pilosa as a multidecadal environmental archive for the Adriatic and Mediterranean Seas. Mar. Environ. Res. 119, 79-87.

Poppe, G.T., Goto, Y., 2000. European Seashells, Volume II: Scaphopoda, Bivalvia, 
Cephalopoda. ConchBooks, Hackenheim.

Prendergast, A.L., Versteegh, E.A.A., Schöne, B.R., 2017. New research on the development of high-resolution palaoenvironmental proxies from geochemical properties of biogenic carbonates. Palaeogeogr. Palaeoclimatol. Palaeoecol. 484, 1-6.

Purroy Albet, A., 2017. The Biological and Ecological Drivers of Shell Growth in Bivalves. Universty of Split, Croatia (PhD thesis, 201 pp.).

Purroy, A., Šegvić-Bubić, T., Holmes, A., Bušelić, I., Thébault, J., Featherstone, A., Peharda, M., 2016. Combined use of morphological and molecular tools to resolve species mis-identification in the Bivalvia - the case of Glycymeris glycymeris and G. pilosa. PLoS ONE 11 (9), e0162059.

Reynolds, D.J., Butler, P.G., Williams, S.M., Scourse, J.D., Richardson, C.A., Wanamaker Jr., A.D., Austin, W.E.N., Cage, A.G., Sayer, M.D.J., 2013. A multiproxy reconstruction of Hebridean (NW Scotland) spring sea surface temperatures between AD 1805 and 2010. Palaeogeogr. Palaeoclimatol. Palaeoecol. 386, 275-285.

Reynolds, D.J., Scourse, J.D., Halloran, P.R., Nederbragt, A.J., Wanamaker, A.D., Butler, P.G., Richardson, C.A., Heinemeier, J., Eiríksson, J., Knudsen, K.L., Hall, I.R., 2016. Annually resolved North Atlantic marine climate over the last millennium. Nat. Commun. 7, 13502.

Richardson, C.A., Peharda, M., Kennedy, H., Kennedy, P., Onofri, V., 2004. Age, growth rate and season of recruitment of Pinna nobilis (L) in the Croatian Adriatic determined from Mg:Ca and Sr:Ca shell profiles. J. Exp. Mar. Biol. Ecol. 299, 1-16.

Royer, C., Thébault, J., Chauvaud, L., Olivier, F., 2013. Structural analysis and paleoenvironmental potential of dog cockle shells (Glycymeris glycymeris) in Brittany, northwest France. Palaeogeogr. Palaeoclimatol. Palaeoecol. 373, 123-132.

Schöne, B.R., 2013. Arctica islandica (Bivalvia): a unique paleoenvironmental archive of the northern North Atlantic Ocean. Glob. Planet. Chang. 111, 199-225.

Schöne, B.R., Gillikin, D.P., 2013. Unraveling environmental histories from skeletal diaries - Advances in sclerochronology. Palaeogeogr. Palaeoclimatol. Palaeoecol. $373,1-5$.

Schöne, B.R., Surge, D. (Eds.), 2005. Looking back over skeletal diaries — high-resolution environmental reconstructions from accretionary hard parts of aquatic organisms. Palaeogeogr. Palaeoclimatol. Palaeoecol. 228, 1-3.

Schöne, B.R., Fiebig, J., Pfeiffer, M., Gleß, R., Hickson, J., Johnson, A.L.A., Dreyer, W., Oschmann, W., 2005. Climate records from a bivalve Methusalah (Arctica islandica, Mollusca; Iceland). Palaeogeogr. Palaeoclimatol. Palaeoecol. 228, 130-148.
Schöne, B.R., Wanamaker Jr., A.D., Fiebig, J., Thébault, J., Kreutz, K., 2011. Annually resolved $\delta^{13} \mathrm{C}_{\text {shell }}$ and chronologies of long-lived bivalve mollusks (Arctica islandica) reveal oceanic carbon dynamics in the temperate North Atlantic during recent centuries. Palaeogeogr. Palaeoclimatol. Palaeoecol. 302, 31-42.

Stenni, B., Nichetto, P., Bregant, D., Scarazzato, P., Longinelli, A., 1995. The $\delta^{18}$ O signal of the northward flow of Mediterranean waters in the Adriatic Sea. Oceanol. Acta 18, 319-328.

Thébault, J., Chauvaud, L., 2013. Li/Ca enrichment in great scallop shells (Pecten maximus) and their relationship with phytoplankton blooms. Palaeogeogr. Palaeoclimatol. Palaeoecol. 373, 108-122.

Thébault, J., Chauvaud, L., Clavier, J., Guarini, J., Dunbar, R.B., Fichez, R., Mucciarone, D.A., Morize, E., 2007. Reconstruction of seasonal temperature variability in the tropical Pacific Ocean from the shell of the scallop, Comptopallium radula. Geochim. Cosmochim. Acta 71, 918-928.

Trevisol, A., Bergamasco, A., Montagna, P., Sprovieri, M., Taviani, M., 2012. Antartic seawater temperature evaluation based on stable isotope measurements on Adamussium colbecki shells: kinetic effects vs. isotopic equilibrium. J. Mar. Syst. 126 (SI), 43-55.

Urey, H.C., 1947. The thermodynamic properties of isotopic substances. J. Chem. Soc. P562.

Vilibić, I., Mihanović, H., Janeković, I., Šepić, J., 2016. Modelling the formation of dense water in the northern Adriatic: sensitivity studies. Ocean Model 101, 17-29.

Walliser, E.O., Schöne, B.R., Tütken, T., Zirkel, J., Grimm, K.I.I., Pross, J., 2015. The bivalve Glycymeris planicostalis as a high-resolution paleoclimate archive for the Rupelian (Early Oligocene) of central Europe. Clim. Past 11, 653-668.

Wanamaker, A.D., Kreutz, K.J., Schone, B.R., Maasch, K.A., Pershing, A.J., Borns, H.W., Introne, D., Feindel, S., 2009. A late Holocene paleo-productivity record in the western Gulf of Maine, USA, inferred from growth histories of the long-lived ocean quahog (Arctica islandica). Int. J. Earth Sci. 98, 19-29.

Wanamaker Jr., A.D., Hetzinger, S., Halfar, J., 2011. Reconstructing mid- to high-latitude marine climate and ocean variability using bivalves, coralline algae, and marine sediment cores from the Northern Hemisphere. Palaeogeogr. Palaeoclimatol. Palaeoecol. 302, 1-9.

Witbaard, R., Jansma, E., Sass Klaassen, U., 2003. Copepods link quahog growth to climate. J. Sea Res. 50, 77-83. 